\title{
Prolactin receptor (PRLR) gene polymorphism in Chios, White Karaman and Awassi sheep breeds
}

\author{
Ozge Ozmen', Ibrahim Seker', Okan Ertugrul' ${ }^{2}$ Emel Ozkan ${ }^{3}$ and Nilgun Tekin ${ }^{4}$ \\ 'Department of Animal Breeding, Faculty of Veterinary Medicine, Firat University, Elazig, Turkey, ${ }^{2}$ Department of \\ Genetic, Faculty of Veterinary Medicine, Ankara University, Ankara, Turkey, ${ }^{3}$ Department of Animal Science, Agriculture \\ Faculty, Namık Kemal University, Tekirdag, Turkey, ${ }^{4}$ Central Laboratory Genomics Unit, Biotechnology Institute, Ankara \\ University, Ankara, Turkey
}

\section{Abstract}

The objective of the present study was to determine the polymorphism in the prolactine receptor $(P R L R)$ gene in Chios, White Karaman and Awassi, which are native sheep breeds in Turkey. By means of $P R L R$ gene sequence homology between sheep and humans, two primer pairs were designed for polymerase chain reaction (PCR) amplification within intron 1 and exon 10 of the PRLR gene in sheep. A total of 160 amplicons ( 99 for intron 1 and 61 for exon 10) were subjected to DNA sequence analysis. For intron 1, 6 different haplotypes were determined. For exon 10, 7 different haplotypes were obtained. Some variations determined for exon 10 (g.14A>T p.Q14L; g.160G >A p.D160N; g.166G >A p.E166K; g.167A>T p.E167V; g.176A>T p.H176L; g.206G >A p.S206N; g.208G>A p.G208R) led to changes in the amino acids, but no amino acid changes were determined in $g .2 A>T, g .81 A>G, g .138 A>G$, g.186C $>T$, g.207T $>C$. It was noted in particular that White Karaman and Awassi were similar to each other in both PRLR exon 10 and intron 1 haplotypes, whereas the Chios breed had a different variation.

Keywords: Turkish sheep breeds, prolactin receptor gene, polymorphism

\section{Zusammenfassung}

\section{Prolaktin-Rezeptor (PRLR) Gen-Polymorphismus in Chios, White Karaman und Awassi Schafrassen}

Das Ziel der vorliegenden Studie war es, den Polymorphismus in der Prolaktin-Rezeptor (PRLR)-Gen in Chios, White Karaman und Awassi, die einheimischen Schafrassen in der Türkei sind zu bestimmen. Durch PRLR Gen Sequenzhomologie zwischen Schafen und Menschen, wurden zwei Primerpaare für die Polymerase Kettenreaktion (PCR) im Intron 1 und Exon 10 des Gens PRLR bei Schafen entwickelt. Insgesamt 160 Amplikons (99 für Intron 1 und 61 für Exon 10) wurden DNA-Sequenz-Analyse unterzogen. Für Intron 1 wurden 6 verschiedene Haplotypen bestimmt. Für Exon 10 wurden 7 verschiedene Haplotypen erhalten. Einige Variationen für Exon 10 (g.14A>T p.Q14L bestimmt; g.160G>A p.D160N; g.166G>A p.E166K; g.167A>T p.E167V; g.176A>T p. H176L; g.206G>A p.S206N; g.208G>A p.G208R), um Änderungen in der Aminosäuren führten, aber keine Aminosäure Veränderungen wurden in $g .2 A>T, g .81 A>G, g$ bestimmt $138 \mathrm{~A}>\mathrm{G}, \mathrm{g} .186 \mathrm{C}>\mathrm{T}, \mathrm{g} .207 \mathrm{~T}>\mathrm{C}$. Es war insbesondere $z u$ 
beachten, dass White Karaman und Awassi einander ähnlich in beiden PRLR Exon 10 und Intron 1 Haplotypen wurden, während die Chios Rasse hatte eine andere Variante.

Schlüsselwörter: Turkish Schafrassen, Prolaktin-Rezeptor-Gen, Polymorphismus

\section{Introduction}

Prolactin is an anterior pituitary peptide hormone involved in many different endocrine activities and is essential for reproductive performance. This action is mediated by its receptor. The prolactin receptor $(P R L R)$ has been detected in various tissues including brain, ovary, placenta and uterus in several mammalian species (Shirota et al. 1990, Tzeng \& Linzer 1997, Cassy et al. 1998). The prolactin receptor, encoded by the $P R L R$ gene, is a member of the growth hormone/prolactin receptor gene family containing regions of identical sequences (Bole-Feysot et al. 1998). The prolactin and growth hormone receptors are homologous to receptors for members of the cytokine superfamily (Clevenger et al. 1998). Mice homozygous for null mutations in PRLR are sterile due to a failure of embryonic implantation, demonstrate irregular cycles, have reduced fertilization rates and defective embryonic development (Ormandy et al. 1997, Bole-Feysot et al. 1998, Baran et al. 2002, Grosdemouge et al. 2003), and show impaired maternal behaviour (Lucas et al. 1998). These characteristics make PRLR a strong candidate gene for reproductive traits (Kmiec et al. 2001, Kovaks et al. 2010).

The gene coding for ovine PRLR was mapped on chromosome 16 (Jenkins et al. 2000). In ovine, there are two distinct prolactin receptor isoforms: long $P R L R$ and short $P R L R$ produced by alternative splicing mechanism (Bignon et al. 1997)

The Chios sheep breed has a high milk yield and an outstanding prolificacy. The average litter size is 2.3 and found in western region in Turkey. The Awassi is principally a milk breed, but meat production from this breed is also important and the twinning rate is $10-20 \%$ and found southeast Anatolia in Turkey. The White Karaman is a breed indigenous to Turkey with a twinning rate of 20-30\% and found in central Anatolia in Turkey. (Akcapinar 2000).

It is well known that Chios sheep are highly prolific in comparison with many other breeds.

The objectives of the present study were investigating polymorphisms in the PRLR gene exon 10 and intron 1 by using DNA sequence analysis. Exon 10 encodes most of the cytoplasmic domain, which is essential for signal transductions (Bole-Feysot et al. 1998).

\section{Material and methods}

\section{Animal resources and DNA isolation}

Fifty blood samples each from Chios, White Karaman, and Awassi ewes, with a total of 150 samples were used. Jugular blood samples ( $2 \mathrm{ml}$ per ewe) were collected from each of the animals. These individuals were chosen at randomly to prevent the relationship. Blood samples from sheep representing 10 subpopulations from 3 Turkish native sheep breeds were collected from remote villages belonging to 3 geographic regions in Turkey (Figure 1). Genomic DNA was extracted from the whole blood using the Phenol-chloroform method and then it was dissolved in $10 \mathrm{mM}$ Tris- $\mathrm{HCl}(\mathrm{pH} 8.0)$ buffer and kept at $-20^{\circ} \mathrm{C}$. 


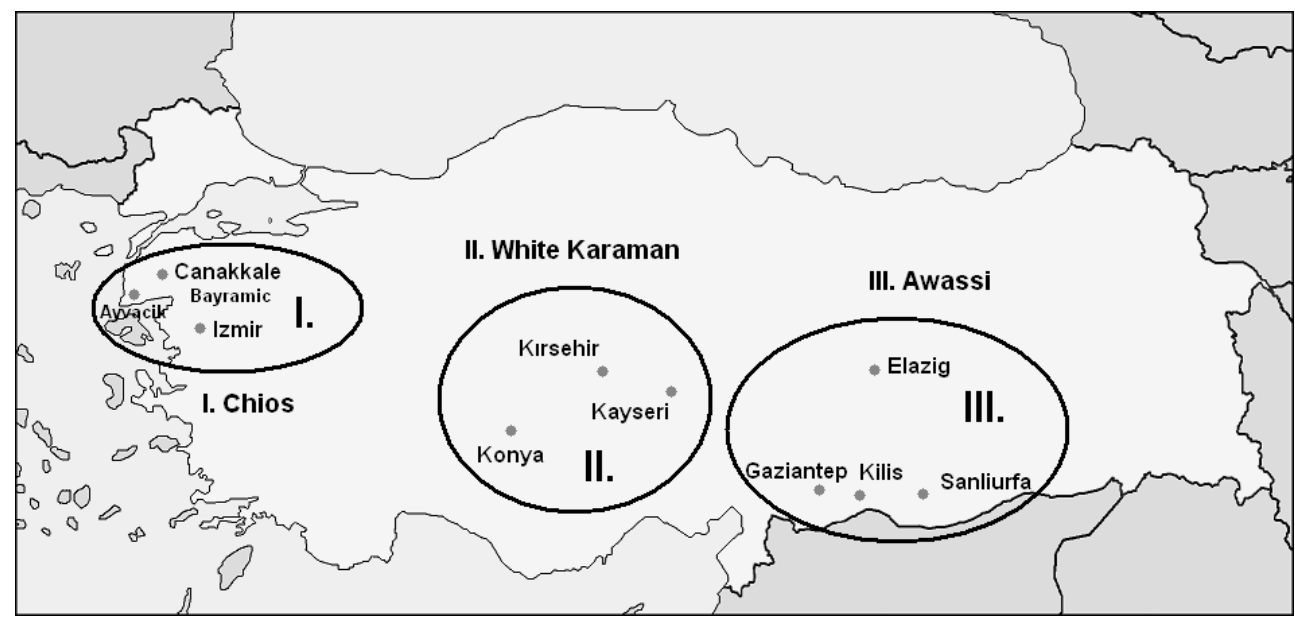

Figure 1

Geographic distribution of Turkish sheep samples

\section{$P C R$ amplifications and sequence analysis}

PCR amplification for exon 10 and intron 1 (267 and 391bp in length) of the PRLR gene was amplified and sequenced using primers and the PCR conditions described by Chu et al. (2007). The PCR products, after being purified with the GeneClean Turbo PCR Purification Kit, were sequenced in CEQ 8000 capillary electrophoresis system (Beckman Coulter). The sequencing was done at the Ankara University Biotechnology Institute. Fifty blood samples each of breeds were used for sequence analysis, however, successful results were obtained in only 34 (White Karaman), 37 (Awassi) and 29 (Chios) samples for intron 1 and 18 (White Karaman), 15 (Awassi) and 28 (Chios) samples for exon 10. Sequences were analysed using the BIOEDIT software (Hall 2007, http://www.mbio.ncsu.edu./BioEdit/bioedit.html) for sequence alignment. NETWORK 4.5.1.6. (Bandelt et al. 1999, http://www.fluxus-engineering.com) was used to build the network of intron 1 and exon 10 haplotype groups using the median joining algorithm. MEGA version 4.1 (Tamura et al. 2007, http://www.megasoftware.net) was used for the phylogenetic sequence analyses of haplotypes by the Neighbour-Joining method based on Kimura-2P model and the reliability of the inferred tree was assessed by bootstrap (1 000 replicates) (data not shown).

The DnaSP software 5 (Rozas et al. 2003) was used to calculate haplotype diversity $\left(\mathrm{H}_{\mathrm{d}}\right)$ and nucleotide diversity ( $\pi$ ); Watterson's theta estimator for the studied species separately using a haplotype sequence was obtained. $\mathrm{Pi}$ is based on the average number of nucleotide differences between the sequence, and theta is based on the total number of segregating sites in the sequence (Iso-Touru et al. 2009).

To estimate the effect of selection, we calculated Tajima's D (Tajima 1989), Fu and Li's D* and $F^{*}$ test (Fu \& Li 1993) and Fu's Fs test (Fu 1997) for each group separately. Tajima's D test compares the difference between the number of segregating sites and average number of pairwise (Tajima 1989). Under neutrality Tajima's D value is assumed to be zero; under 
positive selection there is an excess of rare polymorphisms and Tajima's $D$ value is negative. Negative $D$ values can also be due to population expansion. If there is balancing selection, intermediate frequency genetic variants are kept and Tajima's D value is positive (Iso-Touru et al. 2009). The statistical analysis package DnaSP 5 (Rozas et al. 2003) was used for the neutrality tests.

The impact of amino acid variants on protein structure via analysis of multiple sequence alignments was done with SIFT (Sorting Intolerant From Tolerant), which uses sequence homology to predict whether an amino acid substitution will affect protein function and hence, potentially alter the phenotype. It gives a normalized probability score value that the amino acid change is tolerated. If the score value is less than 0.05 , the amino acid change is predicted to be deleterious. The median conservation value for the diversity of the sequence in the alignment is measured as well, and the default value is 3.0. Higher conservation values can lead to higher false positive error (Pauline \& Henikoff 2003).

\section{Results and discussion}

In this study, the sequence analysis of the intron 1 and exon 10 of the PRLR gene revealed interesting variations in the studied populations and subpopulations. For exon 10, except for reference sequence (AF041257 haplotype 1 [H1]), seven different haplotypes were obtained (Table 1). The most common haplotype was haplotype 5 (H5) for the Chios breed and haplotype $3(\mathrm{H} 3)$ for White Karaman and Awassi. Haplotypes 4-8 $(\mathrm{H} 4-\mathrm{H} 8)$ were not detected in either the White Karaman or Awassi breeds. For intron 1, 6 different haplotypes were determined (Table 2). The most common haplotypes were haplotype $2(\mathrm{H} 2)$ for White Karaman and haplotype $4(\mathrm{H} 4)$ for Awassi. However, haplotype $6(\mathrm{H} 6)$ was the most common for the Chios breed. These haplotypes were determined based on reference sequence AF042358 and called $\mathrm{H} 1$ in this study. Twelve variations were determined in exon 10, of which seven were non-synonymous mutations: g.14A $>$ T p.Q14L; g.160G $>$ A p.D160N; g.166G $>A$ p.E166K; g.167A>T p.E167V; g.176A>T p.H176L; g.206G>A p.S206N and g.208G>A p.G208R; while five variations ( $g .2 A>T, g .81 A>G, g .138 A>G, g .186 C>T, g .207 T>C$ ) were determined as synonymous mutations (Table 1). The PRLR haplotype sequences from these sheep breeds have been deposited in the GeneBank database under the acc. no. HM437203 - HM437214.

Based on the observed mismatch distributions and the constructed radiation tree (Figure 2), two main groups were determined with each primer (Table 3). Neutrality tests were applied separately to these haplotype groups.

Neutrality tests at PRLR gene, Tajima's D value, Fu and Li's $D^{*}$ and F* values and Fu's Fs values are shown in Table 3. Tajima's D value, Fu and Li's $D^{*}$ and F* values and Fu's Fs values for intron 1 group A are positive and the others negative. Artificially selected populations, like livestock species, do not fulfil the assumptions of random mating and constant population size for the neutrality test, hence positive Tajima's D values are likely due to the demographic histories of these species or breeds rather than true balancing selection (Iso-Touru et al. 2009). Haplotype diversity (Hd), nucleotide diversity (pi) and Watterson's theta estimator were calculated separately for the studied species using the haplotype sequences obtained. Since in all groups nucleotide diversities were low but haplotype diversities were high, recent population growth is suggested. 
Table 1

Polymorphic sites (excluding the ambiguous ones) and amino acid changes at the PRLR gene exon 10 for the Turkish sheep breeds. Nucleotides are numbered from 1 to 225, using AF041257 as the reference sequence.

\begin{tabular}{|c|c|c|c|c|c|c|c|c|c|c|c|c|c|c|c|}
\hline $\begin{array}{l}\text { Haplotypes } \\
\text { (Genebank acc. I }\end{array}$ & & $\begin{array}{l}\text { Haplotype } \\
\text { frequency }\end{array}$ & & \multirow[b]{2}{*}{2} & \multirow[b]{2}{*}{1} & \multirow{4}{*}{$\begin{array}{l}8 \\
1\end{array}$} & \multirow{4}{*}{$\begin{array}{l}1 \\
3 \\
8\end{array}$} & \multirow{4}{*}{$\begin{array}{l}1 \\
6 \\
0\end{array}$} & \multirow{4}{*}{$\begin{array}{l}1 \\
6 \\
6\end{array}$} & \multirow{4}{*}{\multicolumn{2}{|c|}{$\begin{array}{l}1 \\
7 \\
6\end{array}$}} & \multirow{4}{*}{$\begin{array}{l}1 \\
8 \\
6\end{array}$} & \multirow{4}{*}{\multicolumn{2}{|c|}{$\begin{array}{l}2 \\
0 \\
6 \\
6\end{array}$}} & \\
\hline & \multirow{3}{*}{$\begin{array}{c}\text { White Karaman } \\
\text { (n:18) }\end{array}$} & \multirow{3}{*}{$\begin{array}{c}\text { Awassi } \\
\text { (n:15) }\end{array}$} & & & & & & & & & & & & & \\
\hline & & & Chios & & 4 & & & & & & & & & & \\
\hline & & & $(\mathrm{n}: 28)$ & & & & & & & & & & & & \\
\hline & & & $\mathrm{AA}$ & & Q & & & D & E & $E$ & $\mathrm{H}$ & & $S$ & & G \\
\hline & & & change & & 1 & & & 1 & 1 & 1 & 1 & & 2 & & 2 \\
\hline & & & & & 4 & & & 6 & 6 & 6 & 7 & & 0 & & 0 \\
\hline & & & & & $\mathrm{L}$ & & & 0 & 6 & 7 & 6 & & 6 & & 8 \\
\hline & & & & & & & & $\mathrm{N}$ & $\mathrm{K}$ & V & L & & $\mathrm{N}$ & & $\mathrm{R}$ \\
\hline H1 (AF041257) & & & & A & A & A & A & G & G & $A$ & A & $C$ & G & $\mathrm{T}$ & G \\
\hline H2 (HM437203) & 9 & 7 & 1 & $\mathrm{~T}$ & . & G & G & . & A & . & . & . & . & . & . \\
\hline H3 (HM437204) & 9 & 8 & 2 & $\mathrm{~T}$ & . & G & G & . & . & . & . & . & . & . & . \\
\hline H4 (HM437205) & 0 & 0 & 2 & $\mathrm{~T}$ & . & . & G & A & . & . & $\mathrm{T}$ & $\mathrm{T}$ & A & C & A \\
\hline H5 (HM437206) & 0 & 0 & 12 & $\mathrm{~T}$ & . & . & G & A & . & . & $\mathrm{T}$ & $\mathrm{T}$ & A & C & . \\
\hline H6 (HM437207) & 0 & 0 & 1 & $\mathrm{~T}$ & . & . & G & A & . & $\mathrm{T}$ & $\mathrm{T}$ & $\mathrm{T}$ & A & $\mathrm{C}$ & . \\
\hline H7 (HM437208) & 0 & 0 & 8 & $\mathrm{~T}$ & $\mathrm{~T}$ & . & G & A & . & . & $\mathrm{T}$ & $\mathrm{T}$ & A & C & . \\
\hline H8 (HM437209) & 0 & 0 & 2 & $\mathrm{~T}$ & $\mathrm{~T}$ & . & G & A & . & . & $\mathrm{T}$ & $\mathrm{T}$ & A & C & A \\
\hline
\end{tabular}

Table 2

Polymorphic sites (excluding the ambiguous ones) at the PRLR gene intron 1 for the Turkish sheep breeds. Nucleotides are numbered from 1 to 302, using AF042358 as the reference sequence.

\begin{tabular}{|c|c|c|c|c|c|c|c|c|c|c|}
\hline \multicolumn{11}{|c|}{ Haplotypes (Genebank acc. no.) } \\
\hline & \multirow{3}{*}{$\begin{array}{l}\text { White Karaman } \\
(\mathrm{n}: 34)\end{array}$} & \multirow{3}{*}{$\begin{array}{c}\text { Awassi } \\
(\mathrm{n}: 37)\end{array}$} & \multirow{3}{*}{$\begin{array}{l}\text { Chios } \\
(\mathrm{n}: 29)\end{array}$} & \multirow{3}{*}{$\begin{array}{l}4 \\
9\end{array}$} & \multirow{3}{*}{$\begin{array}{l}5 \\
8\end{array}$} & \multirow{3}{*}{$\begin{array}{l}2 \\
0 \\
1 \\
\end{array}$} & \multirow{3}{*}{$\begin{array}{l}2 \\
3 \\
4\end{array}$} & \multirow{3}{*}{$\begin{array}{l}2 \\
4 \\
2 \\
\end{array}$} & \multirow{3}{*}{$\begin{array}{l}2 \\
7 \\
2\end{array}$} & \multirow{3}{*}{$\begin{array}{ll}2 & 3 \\
8 & 0 \\
1 & 0\end{array}$} \\
\hline & & & & & & & & & & \\
\hline & & & & & & & & & & \\
\hline H1 (AF042358) & 2 & 1 & 2 & C & $A$ & G & C & C & C & $C A$ \\
\hline H2 (HM437210 & 21 & 10 & 0 & . & . & . & . & . & $\mathrm{T}$ & . . \\
\hline H3 (HM437211) & 4 & 8 & 1 & $\mathrm{~T}$ & . & . & . & . & $\mathrm{T}$ & . . \\
\hline H4 (HM437212) & 7 & 17 & 5 & . & . & $A$ & . & . & $\mathrm{T}$ & . . \\
\hline H5 (HM437213) & 0 & 1 & 0 & $\mathrm{~T}$ & . & $A$ & . & . & $\mathrm{T}$ & . . \\
\hline H6 (HM437214) & 0 & 0 & 21 & . & $\mathrm{C}$ & . & $\mathrm{T}$ & G & $\mathrm{T}$ & $T G$ \\
\hline
\end{tabular}

Table 3

Diversity and neutrality indices in intron 1 and exon 10 PRLR gene

\begin{tabular}{lllll}
\hline & $\begin{array}{l}\text { Intron 1 } \\
\text { group B }\end{array}$ & $\begin{array}{l}\text { Intron 1 } \\
\text { group A }\end{array}$ & $\begin{array}{l}\text { Exon 10 } \\
\text { group B }\end{array}$ & $\begin{array}{l}\text { Exon 10 } \\
\text { group A }\end{array}$ \\
\hline Haplotype number & 1 & 5 & 5 & 3 \\
Nucleotide diversity $(\pi)$ & 0.00063 & 0.00219 & 0.00348 & 0.00515 \\
Haplotype diversity $(\mathrm{Hd})$ & 0.186 & 0.584 & 0.610 & 0.695 \\
Theta $\left(\theta_{\mathrm{w}}\right)$ & 0.55590 & 0.60570 & 0.79450 & 1.19773 \\
Tajima's & -1.51414 & 0.18769 & -0.04533 & -0.09643 \\
Fu \& Li's F* & -2.21420 & 0.75032 & -0.18302 & -0.60514 \\
Fu \& Li's D* & -2.08204 & 0.84631 & -0.20284 & -0.70220 \\
Fu's Fs & -1.920 & 0.171 & -1.486 & -0.955 \\
\hline
\end{tabular}


A)

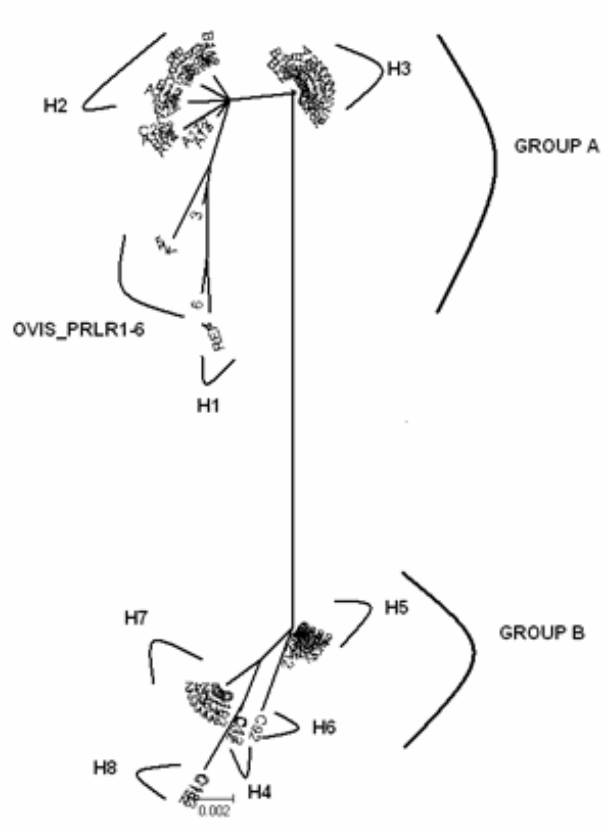

B)

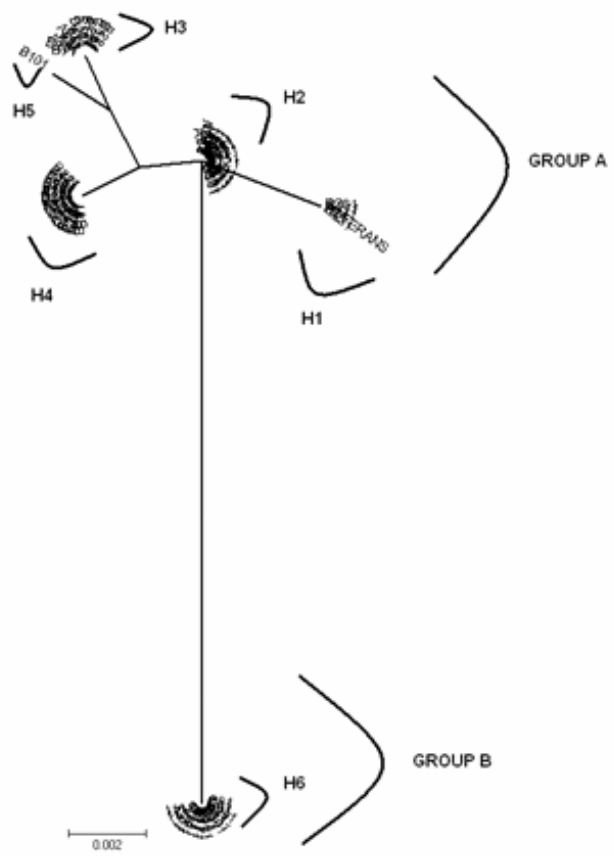

Figure 2

A neighbour-joining phylogenetic tree (radiation style) constructed from exon 10 (A) and intron 1 (B) sequences of $P R L R$ genes from Turkish sheep breeds.

A median joining network for intron 1 and exon 10 is presented in Figure 3 and Figure 4 respectively. For intron 1 haplotypes, $\mathrm{H} 2$ differs from the $\mathrm{H} 1$ by one nucleotide; $\mathrm{H} 3$ and $\mathrm{H} 4$ differ from $\mathrm{H} 1$ by two nucleotides; $\mathrm{H} 5$ differs from $\mathrm{H} 1$ by three nucleotides; $\mathrm{H} 6$ differs by six nucleotides. The most common haplotype for intron 1 is haplotype 2 . Haplotype 6 was observed only in the Chios breed.

The most common haplotype for exon 10 is haplotype 3. For exon 10 haplotypes, $\mathrm{H} 2$ differs from $\mathrm{H} 1$ by four nucleotides; $\mathrm{H} 3$ differs from $\mathrm{H} 1$ by three nucleotides; $\mathrm{H} 5$ differs from $\mathrm{H} 1$ by seven nucleotides; $\mathrm{H} 4, \mathrm{H} 6$ and $\mathrm{H} 7$ differ from $\mathrm{H} 1$ by eight nucleotides; $\mathrm{H} 8$ differs from $\mathrm{H} 1$ by nine nucleotides. Haplotypes 4-8 were observed only in the Chios breed.

We studied the possible impacts of the amino acid changes for the protein structure with the methods implemented in SIFT programs. The substitution p.Q14L and p.E167V was predicted to affect the protein function by SIFT analysis (Table 4). These substitutions were observed only in the Chios breed. 


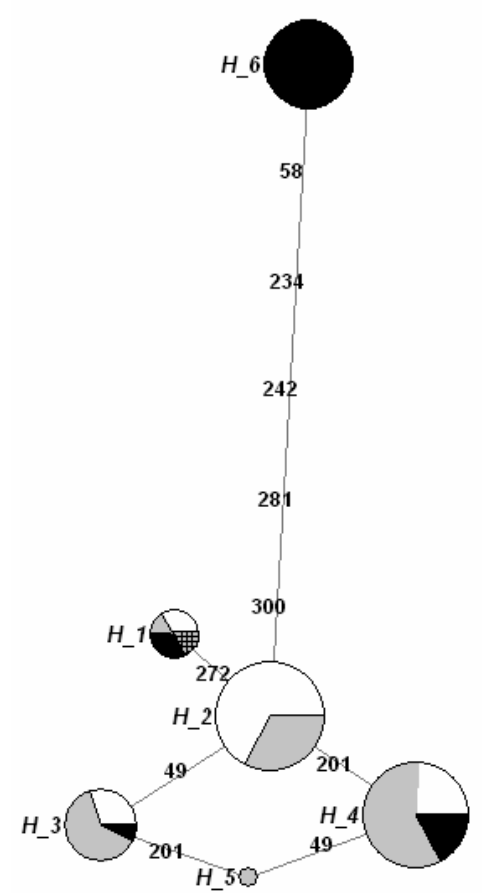

Figure 3

Median joining network for intron 1 haplotype observed in Turkish sheep samples. Different colours represent different sheep breeds. (H1 contains the reference sequence, which is AF0422358)

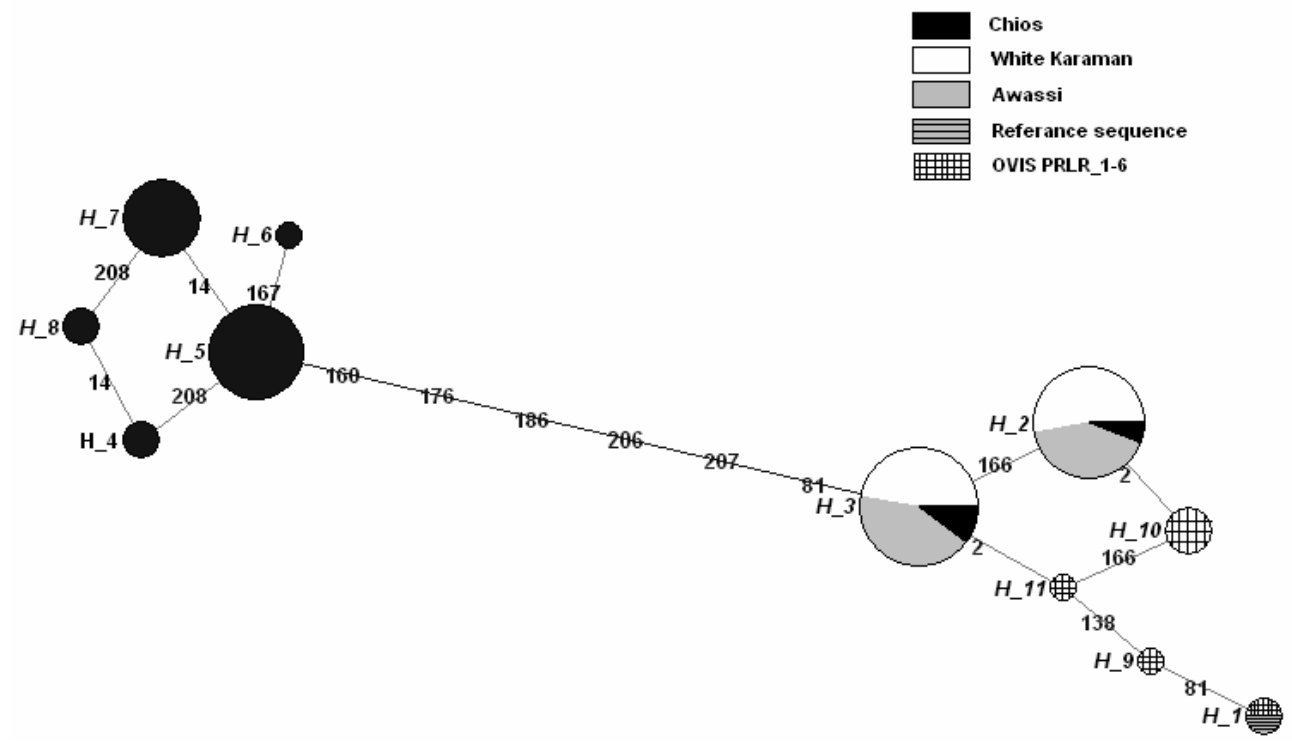

Figure 4

Median joining network for exon 10 haplotype observed in Turkish sheep samples. Different colours represent different sheep breeds. (Quadratic field represents sheep breeds from Russian, Poland and Finland; H1 contains AF041257 and FJ901299; H9 contains FJ901301; H10 contains FJ901296, FJ901297, FJ901300; H11 contains FJ901298 sequence) 
Table 4

Predicted affection status for the amino acid substitutions from PRLR gene exon 10

\begin{tabular}{llcrr}
\hline & & & \\
& SIFT & MSC & $\mathrm{n}$ \\
\hline Q14L & Prediction & Score & 3.45 & 10 \\
D160N & Affect protein function & 0.01 & 3.45 & 25 \\
E166K & Tolerated & 1.00 & 3.45 & 17 \\
E167V & Tolerated & 0.15 & 3.45 & 1 \\
H176L & Affect protein function & 0.03 & 3.45 & 25 \\
S206N & Tolerated & 1.00 & 3.45 & 25 \\
G208R & Tolerated & 0.54 & 3.47 & 4 \\
\hline
\end{tabular}

Studies on the PRLR gene have concentrated more on porcine breeds (Kernerova et al. 2009). A mutation was identified in the porcine PRLR gene (Vincent et al. 1998). An Alul PCR-RFLP polymorphism was identified in the porcine $457 \mathrm{bp}$-long fragment of the $P R L R$ gene (Vincent et al. 1997). A new Hpal PCR-RFLP polymorphism was identified in the porcine PRLR gene (Putnova et al. 2002).

The prolactin receptor (PRLR) gene was studied as a candidate gene for the prolificacy of Jining Grey goats. Five pairs of primers were designed to detect single nucleotide polymorphisms of exon 10 by PCR-SSCP. Only the products amplified by primers P1, P2, P4 displayed polymorphisms. For primer $\mathrm{P} 1$ and primer $\mathrm{P} 2$ sequencing revealed two mutations (g.186G $>$ A and g.220T>C; g.52G $>$ A and g.122G $>$ A, respectively) and for primer $\mathrm{P} 4$, sequencing revealed one mutation (g.143A $>\mathrm{G}$ ) of the $P R L R$ gene (Zhang et al. 2007).

The sheep PRLR gene has been screened for polymorphisms by PCR-SSCP (Mu et al. 2006). Three genotypes (AA, AB and BB) were detected by three primer pairs. Chu et al. (2007) had detected ovine PRLR gene polymorphism by PCR-SSCP. Three primer pairs were designed for PCR amplification within intron 1 and exon 10 of the PRLR gene in sheep.

The mutations we noticed ( $g .272 \mathrm{C}>\mathrm{T}$ ) were identical for each breed to those reported by Chu et al. (2007) who found position g.84 T>C in intron 1. These investigators had used two primer pairs (termed primer 1 and primer 2) for intron 1 of the ovine PRLR gene amplification. In the present study, we used one primer pair (391bp) for intron 1 PRLR gene amplification.

Iso-Touru et al. (2009) sequenced PRLR gene exon 10 (891bp), coding for the major part of cytoplasmic domain, from 6 different sheep breeds (Romanov breed, Wrzosowka breed, Dagestan local, Andi, sheep from Komi village, Finnsheep and Alandsheep). These researchers were found 6 different haplotypes, which is OVIS_PRLR1-OVIS_PRLR6 (GenBank acc. no.: FJ901296-FJ901301).

For exon 10, network analysis was performed with Iso-Touru et al. (2009) haplotypes (Figure 4). Accordingly, these haplotypes [H1 (FJ901299), H9 (FJ901301), H10 (FJ901296; FJ901297; FJ901300), H11 (FJ901298)] differ from H2 by g.2A>T variation. H2 appeared in the White Karaman and Awassi breeds. Moreover, g.81A>G, g.138A $>\mathrm{G}$ and g.166G $>\mathrm{A}$ were determined in the White Karaman and Awassi breeds, as reported for the Russian, Finnish and Polish sheep breeds, which appeared to be the same group based on Haplotype 2 and 3 . The Chios breed differs from the White Karaman, Awassi, Russian, Polish and Finnish breeds.

As a result, this suggests that population expansion can be based on the negative neutrality test values obtained in intron 1 group $B$ and exon 10 groups $A$ and $B$. Under positive selection there is an excess of rare polymorphisms and Tajima's D, Fu and Li's D and F values and Fu's Fs 
values are negative. Both population and subpopulation variations for intron 1 and exon 10 of the PRLR gene polymorphisms were found in Chios, White Karaman and Awassi ewes. It was interesting to note that White Karaman and Awassi sheep were similar to each other in terms of both intron 1 and exon 10 haplotypes, whereas the Chios breed had different variations.

The Chios breed showed greater and different haplotype diversity and different variations in comparison with White Karaman and Awassi. Whether other gene(s) or quantitative trait loci (QTL) regulating ovulation are also present requires further research. We propose that this difference is probably the consequence of different environmental conditions, selection and possibly even QTL or gene(s) regulating ovulation rate.

In the present study, intron 1 and exon 10 of the ovine PRLR gene polymorphisms were screened by the sequencing technique. We have reported here for the first time single nucleotide polymorphisms of the PRLR gene for both intron 1 and exon 10 in Turkish sheep breeds. We concluded that the identified SNPs lend themselves readily for further research regarding physiological impacts such as milk production and reproductive traits in livestock.

\section{Acknowledgements}

The sequence experiments were carried out at the Ankara University Biotechnology Institute Genomics Unit. The Project was supported by Tubitak and Scientific Research Projects Council of Firat University (Project code Tubitak 1070894; Fubap: 1502 ).

\section{References}

Akcapinar H (2000) Sheep Breeding, 2nd ed., Ankara, Turkey

Bandelt H-J, Forster P, Röhl A (1999) Median-joining networks for inferring intraspecific phylogenies. Mol Biol Evol 16, 37-48

Baran N, Kelly PA, Binart N (2002) Characterization of a prolactin-regulated gene in reproductive tissues using the prolactin receptor knockout mouse model. Biol Reprod 66, 1210-1218

Bignon C, Binart N, Ormandy C, Schuler LA, Kelly PA, Djiane J (1997) Long and short forms of the ovine prolactin receptor: $\mathrm{CDNA}$ cloning and genomic analysis reveal that the two forms arise by different alternative splicing mechanisms in ruminants and in rodents. J Mol Endocrinol 19, 109-120

Bole-Feysot C, Goffin V, Edery M, Binart N, Kelly PA (1998) Prolactin (PRL) and its receptor: Actions, signal transduction pathways and phenotypes observed in PRL receptor knockout mice. Endocr Rev 19, 225-268

Cassy S, Charlier M, Belair L, Guillomot M, Charron G, Bloch B, Djiane J (1998) Developmental expression and localization of the prolactin receptor $(P R L R)$ gene in ewe mammary gland during pregnancy and lactation: Estimation of the ratio of the two forms of PRLR messenger ribonucleic acid. Biol Reprod 58, 1290-1296

Chu MX, Mu YL, Fang L, Ye SC, Sun SH (2007) Prolactin receptor as a candidate gene for prolificacy of Small Tail Han sheep. Anim Biotechnol 18, 65-73

Clevenger CV, Freier DO, Kline JB (1998) Prolactin receptor signal transduction in cells of the immune system. J Endocrinol 157, 187-197

Fu YX (1997) Statistical tests of neutrality of mutations aganist population growth, hitchhiking and background selection. Genetics $147,915-925$

Fu YX, Li WH (1993) Statistical tests of neutrality of mutations. Genetics 133, 693-709

Grosdemouge I, Bachelot A, Lucas A, Baran N, Kelly PA, Binart N (2003) Effects of deletion of the prolactin receptor on ovarian gene expression. Reprod Biol Endocrinol 1, 12

Hall T (2007) BioEdit 7.0.9, http://www.mbio.ncsu.edu./BioEdit/bioedit.html [last accessed 29.08.2011] 
Iso-Touru T, Kantanen J, Li MH, Gizejewki Z, Vilkki J (2009) Divergent evolution in the cytoplasmic domains of PRLR and GHR genes in Artiodactyla. BMC Evol Biol 9, 172

Jenkins ZA, Henry HM, Sise JA, Montgomery GW (2000) Follistatin (FST), growth hormone receptor (GHR), and prolactin receptor (PRLR) genes map to the same region of sheep chromosome 16. Anim Genet 31, 280

Kernerová N, Matoušek V, Čermáková A, Forbelská M (2009) Role of genetic markers in the prediction of classification of Czech Large White gilts to a hyperprolific line. Arch Tierz 52, 40-50

Kmiec M, Dybus A, Terman A (2001) Prolactin receptor gene polymorphism and its association with litter size in Polish Landrace. Arch Tierz 44, 547-551

Kovacs K, Fesus L, Zsolnai A, Nyiri A, Anton I (2010) Porcine prolactin receptor genotypes and production and reproduction traits in Hungarian Large White and Landrace sows (Brief Report). Arch Tierz 53, 497-499

Lucas BK, Ormandy CJ, Binart N, Bridges RS, Kelly PA (1998) Null mutation of the prolactin receptor gene produces a defect in maternal behavior. Endocrinol 139, 4102-4107

Mu YL, Chu MX, Su SH, Fang L, Ye SC (2006) PCR-SSCP Analysis on prolactin receptor gene in sheep. Acta Vet Zoot $\operatorname{Sin} 10,956-960$ [in Chinese]

Ormandy CJ, Camus A, Barra J, Damotte D, Lucas B, Buteau H, Edery M, Brousse N, Babinet C, Binart N, Kelly PA (1997) Null mutation of the prolactin receptor gene produces multiple reproductive defects in the mouse. Genes Dev 11, 167-178

Pauline CN, Henikoff S (2003) SIFT: prediciting amino acid changes that affect protein function. Nucleic Acids Res 31, 3812-3814

Putnová L, Knoll A, Dvoŕak J, Čepica S (2002) A new Hpall PCR-RFLP within the porcine prolactin receptor (PRLR) gene and study of its effect on litter size and number of teats. J Anim Breed Genet 119, 57-63

Rozas J, Sanchez DelBarrio JC, Messeguer X, Rozas R (2003) DnaSP, DNA polymorphism analyses by the coalescent and other methods. Bioinform 19, 2496- 2497

Shirota M, Banville D, Ali S, Jolicoeur C, Boutin JM, Edery M, Djiane J, Kelly PA (1990) Expression of two forms of prolactin receptor in rat ovary and liver. Mol Endocrinol 4, 1136-1143

Tajima F (1989) Statistical method for testing the neutral mutation hypothesis by DNA polymorphism. Genet $123,585-595$

Tamura K, Dudley J, Nei M, Kumar S (2007) MEGA4: Molecular evolutionary genetics analysis (MEGA) software version 4.0. Mol Biol Evol 24, 1596-1599

Tzeng SJ, Linzer DI (1997) Prolactin receptor expression in the developing mouse embryo. Mol Reprod Dev $48,45-52$

Vincent AL, Wang L, Tuggle CK, Robic A, Rothschild MF (1997) Prolactin receptor maps to pig chromosome 16. Mamm Genome 8, 793-794

Vincent AL, Evans G, Short TH, Southwood OI, Plastow GS, Tuggle CK, Rothschild MF (1998) The prolactin receptor gene is associated with increased litter size in pigs. Proceeding 6th World Congress on Genetics Applied to Livestock Production. Armidale 27, 15-18

Zhang GX, Chu MX, Wang JY, Fang L, Ye SC (2007) Polymorphism of exon 10 of prolactin receptor gene and its relationship with prolificacy of Jining Grey goats. Yi Chuan 29, 329-336 [in Chinese]

Received 30 November 2010, accepted 7 March 2011.

Corresponding author:

Ozge Ozmen

email: oozmen@firat.edu.tr or ozgeozmen@gmail.com

Department of Animal Breeding, Faculty of Veterinary Medicine, Firat University, TR-23119 Elazig, Turkey 